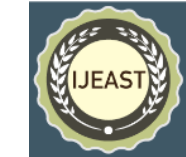

\title{
A COMPARATIVE STUDY ON SCHOOL
} ENVIRONMENT AS EXPERIENCED BY \section{ADOLESCENTS IN URBAN AND RURAL GOVERNMENT CO-EDUCATIONAL SCHOOLS OF MALWA REGION IN PUNJAB, STATE OF INDIA}

\author{
Simranjit Kaur \\ Research Scholar \\ Department of Education \\ Panjab University, Chandigarh
}

\begin{abstract}
The purpose of the study was to assess the school environment as experienced by adolescents in urban and rural government schools of Malwa Region in Punjab, State of India. Descriptive survey method was employed to fulfill the objectives of the study. A sample of 200 adolescent students (100 boys and 100 girls) of class IX were selected from four randomly selected urban and rural government schools. School Environment Inventory by K.S Mishra (2013) tool was used to collect quantitative data and Interview technique was used to collect qualitative data from the respondents. The results of the study derived from the application of parametric tests displayed significant difference in the six dimensions namely creative stimulation, cognitive encouragement, acceptance, permissiveness, control and rejection of school environment experienced by adolescents in urban and rural government schools.
\end{abstract}

Key Words - School Environment, Type of School (Urban \& Rural), Gender (Boys and Girls)

\section{INTRODUCTION}

The first school of the child is their home and school is the second and formal school where the child polishes his abilities to become a successful person in life and enable himself to serve the country. Proper utilisation of human resource is possible if the environment of the school is conducive where a child receives all the supportive facilities that help him to avoid failures in life. School environment is made up of living and non living resources in which teachers, students, staff belongs to human resources category and all other without breathing aiding sources connected with the second non living category like physical facilities, activities, aiding processess etc. these helpful sources shaping students' creative and critical thinking, make them socially, physically and emotionally strong, enable them to become good human being for the betterment of their families, neighbourhood, city, state, then for whole country. A healthy relationship between teachers and students always create good moral value among students that gives right direction to the learners for choosing right path in their life. Coordination between teachers and staff and decentralized system of the school creates healthy environment and give motivation to the leader of the school to run their functions effectively. Many researches revealed that flexible school environment has positive impact on academic learning of the students. According to Gill (2016) there are three main factors which affect a study environment that includes illumination or lighting which influence student's academic learning, noise pollution which distracts the concentration of the student and interruption created by school itself like student - unrest or social evils etc. For avoiding the wastage of human potential and finding out the unknown potential of the student, the school environment should be healthy and positive. Zais (2011) said that "School Environment means the extent to which school settings promote student safety and student health, which may include topics such as the physical plant, the academic environment, available physical and mental health supports and services, and the fairness and adequacy of disciplinary procedures, as supported by relevant research and an assessment of validity".

Misra (2013) mentioned six dimensions of the school environment that includes (a) Creative Stimulation: it refers to "teacher's activities to provide conditions and opportunities to stimulate creative thinking." (b) Cognitive Encouragement: it means "teacher's behavior to stimulate cognitive development of students by encouraging his actions or behaviors". (c) Permissiveness: It indicates "a school climate in which students are provided opportunities to express their views freely and act according to their desires with no interruption from teachers". (d) Acceptance: this dimension refers to "Expecting feelings of the students and their ideas in the class". (e) Rejection: it means "a school climate in which teachers do not accord recognition to students' rights to deviate, act freely and be autonomous persons." (f) Control: it refers to "autocratic atmosphere of the school in which several restrictions are imposed on students to discipline them". 


\section{Operational definition}

School environment may be described as formal atmosphere created by the school family members itself i.e teachers, students, staff and leader, which influence their overall personality development. The school environment was measured by the School Environment inventory by K.S. Misra (2013). It has six dimensions creative stimulation, cognitive encouragement, permissiveness, control, acceptance and rejection.

\section{REVIEW OF RELATED LITERATURE}

Koepakke and Harkins (2008) collected a data from 698 (333 boys and 365 girls) from kindergarten to $4^{\text {th }}$ grade and 35 teachers from Northeastern United States to examine the gender differences in the teacher-child relationship that influence the school environment. Significant results were found in teacher-child relationship. Results revealed that more distance and quarrel between boys and their teacher disconnect the boys from self and society that diminishes their academic performance.

Majara and Gur (2010) randomly selected 20 government schools in rural karnataka with the purpose to check the status of school environment and sanitation that influence the learning of the students. Output of the study showed that rural students received unsatisfactory facilities in the schools that hinder their studies than those schools where adequate facilities were available for the students.

Sreekanthachari and Nagaraja (2013) pointed out various differences in urban education and rural education in India. The paper written by the investigators mentioned that urban school students enjoyed all the supportive facilities that increase their learning ability whereas the rural school students face despair for inflexible school environment. The paper also provided the suggestions for the teachers to feel proud by teaching in rural area schools and also acting as helping hand for the students to avoid the educational wastage.

Usaini \& Bakar. N. A. (2015) conducted a study on 377 respondents recruited from four secondary schools situated in Kuala Terengganu, Malaysia, through stratified sampling technique. The study was carried out to find the impact of school environment on the academic output of the students. The results of the study displayed that those school students performed well in the academics, who were receiving flexible environment in the school than those schools where the environment was unsupportive for students.

Anbalagan (2017) recruited 160 students of 9th and 10th standard of rural and urban higher secondary schools in Madurai district to examine the impact of school environment on academic trajectory. The results of the study revealed significant differences between gender observation about school environment and also showed that urban students received better school environment than rural students.

\section{NEED OF THE STUDY}

Hindustan Times (2019) published a reports of NITI AYOG (The National Institution for Transforming India) that assesed the quality of Indian schools education system, in which Punjab secured a performance score 41.14 with 18 th rank (Ranking position was sorted out by grouping states and UTs into large states, small states and Union Territories) in the list among 20 large states and fall under the bottom five states category which was calculated on 30 indicators that were divided into two main categories namely outcome category and Governance Processes Aiding Outcomes category along with domains mentioned in the Niti Ayog's school education quality index (SEQI). Reports exhibited that Punjab state was better in governance aiding indicator category than outcome category and the index focused the efforts of the school to polish the learning abilities of the students. On the basis of the review literature, many studies supported that flexible school environment is helpful in increasing the learning of the students. Thus, the present study was taken up keeping in view about the above mentioned reason for measuring the students' experiences within school environment that connected with their academic trajectory.

\section{OBJECTIVES}

1. To study and compare school environment of adolescents in urban and rural government schools.

2. To study and compare school environment of adolescents boys and girls in urban and rural government schools.

\section{HYPOTHESES}

The following null hypotheses were formulated for the present study.

1. There will be no significant difference in school environment of adolescents in urban and rural government schools.

2. There will be no significant difference in school environment of adolescent boys and girls in urban and rural government schools.

\section{SAMPLE OF THE STUDY}

A sample of 200 adolescent students (100 boys and 100 girls) of class IX were recruited for study purpose from four randomly selected urban and rural co-educational government schools of Malwa Region in Punjab state.

\section{DESIGN AND STATISTICAL METHODS USED FOR THE STUDY}

Descriptive survey method was employed to find out the difference in school environment as observed by urban and rural government co-educational school students in Malwa region of Punjab state. For drawing the results of the study, parametric statistical methods were applied. An inferetial statistic i.e.t-test was used to find out the significant difference between the means of two independent groups

VIII. TOOLS USED 


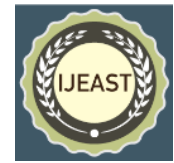

1. School Environment Inventory by K.S Mishra (2013).

2. Interview technique was used to collect qualitative data.

\section{DELIMITATIONS OF THE STUDY}

1. Only 200 adolescent students of class $9^{\text {th }}$ were selected for investigation.

2. It was delimited to two urban government and two rural government co-educational schools situated in Malwa region of Punjab.

3. Only three variables were taken namely school environment, type of school (urban and rural), gender (boys \& girls) for investigation.

\section{X. $\quad$ STATISTICAL HYPOTHESIS TESTING}

For the present study null hypothesis were processed to make the fulfil of the objectives and parametric statistics were applied according to interval nature of the School Environment Inventory 5 point Likert type scale to draw the inferences of the study. Hypotheses tests are used when ascertain what results received from the recruited sample of a present study would lead to a deniel of null hypothesis for predetermined level of significance whether at.05 or.01 level of significance.

\section{A) Testing of hypothesis -1}

Hypothesis-1 states, "There is no significant difference in the six dimensions of School Environment of Urban Government and Rural Government Schools".

Table 1: Mean Standard Deviation; Mean Differentials of School Environment of Adolescents in Urban Government and Rural Government Schools.

\begin{tabular}{|l|l|l|l|l|l|}
\hline $\begin{array}{l}\text { Dimensions of School } \\
\text { Environment }\end{array}$ & $\begin{array}{l}\text { M1 } \\
\text { Govt. } \\
\text { Rural }\end{array}$ & $\begin{array}{l}\text { M2 } \\
\text { Govt. } \\
\text { Urban }\end{array}$ & $\begin{array}{l}\text { S.D1 } \\
\text { Govt. } \\
\text { Rural }\end{array}$ & $\begin{array}{l}\text { S.D2 } \\
\text { Govt. } \\
\text { Urban }\end{array}$ & $\begin{array}{l}\text { t-value } \\
\text { (df=198) }\end{array}$ \\
\hline CRS (A) & 8.76 & 9.63 & 2.61 & 2.83 & $2.08^{*}$ \\
\hline COE (B) & 5.50 & 5.67 & 1.05 & 1.15 & .50 \\
\hline ACC (C) & 5.67 & 5.96 & 1.20 & 2.39 & 1.46 \\
\hline PER (D) & 5.73 & 6.45 & 2.21 & 2.40 & $2.03^{*}$ \\
\hline REJ (E) & 4.81 & 4.66 & 1.74 & 2.04 & .182 \\
\hline CON (F) & 6.40 & 6.48 & 2.03 & 2.14 & .60 \\
\hline
\end{tabular}

Note: * significant at .05 levels

CRS: creative stimulation, COE: cognitive encouragement, ACC: acceptance,

PER: permissiveness, REJ: rejection, CON: control.

\section{RESULTS AND DISCUSSION}

Table 1, represented Mean Standard Deviation; Mean Differentials of School Environment of Adolescents in Urban Government and Rural Government Schools. The calculated tvalue between the mean score of rural and urban government school adolescents with regard to various dimensions of school environment are 2.08, .50, 1.46, 2.03, .182, .60 at 198 degree of freedom out of which only creative stimulation and permissiveness dimension of school environment was found to be significant at 0.05 level of significance. This clearly indicates that there is statistically significant difference in respect to these dimensions among rural and urban government schools of Malwa region of Punjab state.

\section{Interpretation of the results}

Table 1 indicated the significant difference among rural and urban school students regarding creative stimulation dimension and permissiveness dimension of school environment. Mean scores exhibited that creative stimulation of urban schools is high than rural schools. Teachers in urban schools are giving better opportunities to their students that increasing and polishing students' creative thinking and creative process in contrast rural school adolescents receiving less provisions from their teachers to brighten their creative skills. Furthur the mean score of permissiveness dimension of school environment presented that teachers in urban schools give more freedom to their students to express views contradictory to teacher's view, permission to do appropriate activities in class without permission, give chance to learn by their own experiences, and involve in decision making than rural school teachers. Srivastava and Joshi (2011) suggested that school resources are important keys for polishing the abilities and learning of the students. The difference in respect to these dimensions may be due to reason that in urban schools, students come from socially and economically sound families and avail academic things easily whereas students from rural areas struggling with some economic problems because of their parents' occupation like agriculture, stitching, small private business etc. Answers collected through interview technique from respondents showed that rural students were facing physical facilities related problems like noise around the school, unhygenic toilets and kitchen, lack of transportation system, infrastructure and discipline problems etc. The results are in consonance with the results of study conducted by Anbalagan (2017), Majara and Gur (2010) \& Sreekanthachari and Nagaraja (2013). The statistical significant difference between urban and rural gover schools 
were supported by Miah (2015) and Lawrence and Vimala (2012).

B) Testing of hypothesis -2
Hypothesis-2 states, "There is no significant difference in the six dimensions of School Environment of adolescent boys and girls studying in Urban Government and Rural Government Schools".

Table 2: Mean, Standard Deviation, Mean Differentials of School Environment of Adolescent Boys and Girls in Urban Government and Rural Government Schools.

\begin{tabular}{|l|l|l|l|l|l|}
\hline $\begin{array}{l}\text { Dimensions of School } \\
\text { Environment }\end{array}$ & $\begin{array}{l}\text { M1 } \\
\text { Boys }\end{array}$ & $\begin{array}{l}\text { M2 } \\
\text { Girls }\end{array}$ & $\begin{array}{l}\text { S.D1 } \\
\text { Boys }\end{array}$ & $\begin{array}{l}\text { S.D2 } \\
\text { Girls }\end{array}$ & $\begin{array}{l}\text { t-value } \\
\text { (df=198) }\end{array}$ \\
\hline CRS (A) & 5.26 & 5.35 & 1.75 & 1.83 & .205 \\
\hline COE (B) & 6.71 & 6.14 & 2.74 & 2.58 & 1.33 \\
\hline ACC (C) & 5.77 & 6.46 & 2.22 & 2.41 & $2.09^{*}$ \\
\hline PER (D) & 6.30 & 5.98 & 2.38 & 2.30 & 1.30 \\
\hline REJ (E) & 6.54 & 6.62 & 1.97 & 2.22 & .089 \\
\hline CON (F) & 8.36 & 8.56 & 2.25 & 2.00 & .866 \\
\hline
\end{tabular}

Note: * significant at .05 levels

(CRS: creative stimulation, COE: cognitive encouragement, ACC: acceptance,

PER: permissiveness, REJ: rejection, CON: control).

\section{RESULTS AND DISCUSSION}

Table 2 presented, Mean, Standard Deviation, Mean Differentials of School Environment of Adolescent Boys and Girls in Urban Government and Rural Government Schools. The calculated t-value between the mean score of boys and girls in rural and urban government schools with regard to various dimensions of school environment are .205, 1.33, $2.09,1.30, .089, .866$ at 198 degree of freedom out of which only acceptance dimension was found significant at 0.05 level of significance.

\section{Interpretation of the results}

Table 2 indicated the significant difference among girls and boys regarding acceptance dimension of school environment. It reveals that feelings and ideas of the girls are more accepted by the teachers than boys. Teachers expect much from girls than boys in academics, interact more with girls, less believe in boys in respect to classroom activities, more participate in activities with the girls than boys. Teachers become anxious when boys donot come to school but for girls they have flexible attitude. After receiving the responses from sample through interview questions, results showed that teachers gave more preference to the feelings of the girls; it may due to reason that boys have ability to handle their emotions strongly. Boys have better problem solving ability that help them to make emotionally strong (Kaur, 2015). Contrast results were dispalyed by kaur (2017) about significant difference among boys and girls regarding the acceptance. The results are in consonance with the results of the study directed by (Koepakke \& Harkins, 2008). Another reason was reflected in Hindustan times (2016) published news based on received reviews of teachers and students that Punjab government when introduces schemes to motivate girl's education and distribute gifts like cycles and stationary items decline the confidence level of boys and create imbalance among gender.

\section{EDUCATIONAL IMPLICATIONS}

The received results of the study provided few educational implications that will helpful in future to protect the human value. Results direct that proper supportive physical facilities should be available in rural area government schools so that teachers can stimulate creative thinking among students by providing them various opportunities. Government should inspect the unavailable supportive aids in the schools that hinders the progress of the teachers as well as students. Teachers should also act as helping hand in the development of the students for avoiding the failures in academics and nonacademic activities. Equal affection should be shown by the teachers and schools for both the genders to remove social difference stereotyped threat thinking among students. Government should also showing equality to reduce the feeling of imbalance among boys mind regarding the gifts distribution gifts for empowering girls' education.

\section{CONCLUSION}

From the above picture of the study, it can be concluded that healthy school environment plays an important role for avoiding the wastage of human potential. Human and non human resources make the school environment healthy and happier. So, government should timely provide the resources to the schools according to te requirements and schools itself should utilize the available resources in appropriate manner for the betterment of human potential, for society and for country's development.

\section{REFRENCE}

Anbalagan, S. (2017). Impact of school environment on academic achievement of secondary school students in Madurai district. International Journal of Applied Research; $3(5)$ : 732-737. http://www.allresearchjournal.com/archives/2017/vol 3issue5/PartK/3-5-138-510.pdf. 
Gill, S.K. (2016). A Study of Academic Achievement of Senior Secondary School Students in relation to their Anxiety learning styles and School Environment. Ph.D. theses, Shodhganga. https://shodhganga.inflibnet.ac.in/handle/10603/2081 25.

Hindustan Times (2016). Old school bags Vs new: Boys feel ignored as Punjab gives doles to girls. Hindustan Times, Mar 18, $2016 \quad 20: 30 \quad$ IST. https://www.hindustantimes.com/rf/ima 0.

Hindustan Times (2019). Niti Aayog's School Education Quality Index: Rank wise list of states and Uts. Hindustan Times, Updated: Oct 01, 2019 14:37 IST. https://www.hindustantimes.com/education/nitiaayog-s-school-e 0.

Kaur, S. (2015). A Study of Problem Solving Ability among adolescents of senior secondary schools in relation to their emotional stability and personality types. Journal of Education, 5, ISSN No. 0975-8720, 40-43.

Kaur, S. (2017). Comparative study on school environment as percieved by boys and girls. International Journal of Research in Social Sciences, 7(9): 661-680. https://www.ijmra.us/project\%20doc/2017/IJRSS_SE PTEMBER2017/IJMRA-12266.pdf.

Koepakke, M.F. \& Harkins, D. A. (2008) Conflict in the Classroom: Gender Differences in the Teacher-Child Relationship. Journal of Early Education and Development, 19(6), 843-864. As retrieved from https://www.tandfonline.com/action/showCitFormats ?doi $=10.1080 \% 2 \mathrm{~F} 10409280802516108$

On 01/01/2020.

Lawrence, A.S., \& Vimala, A. (2012). School Environment and Academic Achievement of Standard IX Students. Journal of Educational and Instructional Studies In The World, 2 (3), p. 210-215. https://files.eric.ed.gov/fulltext/ED542331.pdf 7.

Majra, J.P. \& Gur, A. (2010). School Environment and Sanitation in Rural India. Journal of Global Infectious Diseases, 2(2): 109-111. https://www.researchgate.net/publication/45097910_ School_Environment_and_Sanitation_in_Rural_India On 25/12/2019.

Miah, A.S. (2015). Influence of School Environment In Relation To the Academic Achievement of Secondary School Students of Malda District, India. Abhinav National Monthly Refereed Journal of Research In Arts \& Education, 4(7), p. 610.https://abhinavjournal.com/journal/index.php/ISS N-2277-1182/article/.../pdf_598.

Mishra, K.S. (2013). School Environment Inventory. Lucknow: Ankur Psychological Agency.
Sreekanthachari, J.G. and Nagaraja, G. (2013). An overviefw of rural education in India. Adv. Res. J. Soc. Sci., 4 (1): 115 119 http://www.researchjournal.co.in/upload/assignments 14_115-119.pdf.

Srivastava, R. and Joshi, S. (2011) The Effect of School and Area on Academic Self-concept and Academic Achievement of Adolescents. Delhi Psychiatry Journal, 14(2), P.331-336. http://medind.nic.in/daa/t11/i2/daat11i2p331.pdf 7.

Usaini, M. I. \& Bakar. N. A. (2015). The Influence of School Environment on Academic Performance of Secondary School Students in Kuala Terengganu, Malaysia. Proceedings of ICIC2015 - International Conference on Empowering Islamic Civilization in the 21st Century e-ISBN: 978-967-13705-0-6. https://www.ijmra.us/project\%20doc/Pdf .

Zais, M. (2011). South Carolina School Environment Initiative. South Carolina Department of Education, Columbia. http://ed.sc.gov/agency/ac/StudentInterventionServices/documents/SCSchoolEnvironmentRFP-Nov2011.pdf.

\section{ACKNOWLEDGEMENT}

I would like to thank you to Almighty for showering blessings on me to complete this project with success. Then I would like to thank you my family members who encouraged me during my work and gave me lessons of life to become a strong person in life. A very special thank you to my guide Dr. Anjali Sharma, whose valuable and precious guidance helped me to patch this project and make it full proof success, received suggestions and instructions, has served as the major contributor towards the completion of this challenge.

I woul like to give special credit to my music field that healed me a lot during the completion of my research paper.

Last but not the least I would like to thank you to myself and my friends who have helped and counselled me a lot. 